Supporting information

\title{
Structural Ordering Supremacy on the Oxygen Reduction Reaction of Layered Iron-Perovskites
}

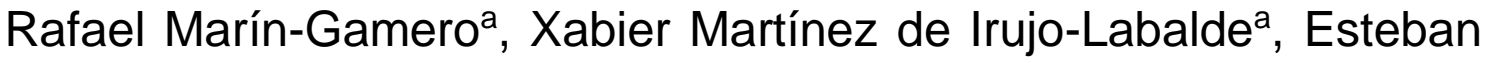
Urones-Garrote ${ }^{a}$, Susana García-Martín ${ }^{\star a}$

Departamento de Química Inorgánica, Facultad de Ciencias Químicas, Universidad Complutense, 28040 Madrid, Spain 


\section{Table of contents}

PXRD patterns of $\mathrm{Gd}_{0.8-\mathrm{x}} \mathrm{Ba}_{0.8} \mathrm{Ca}_{0.4+\mathrm{x}} \mathrm{Fe}_{2} \mathrm{O}_{5+\delta}(\mathrm{x}=0,0.25,0.4)$. Rietveld refinement results.

EELS analysis of $\mathrm{Gd}_{0.8-x} \mathrm{Ba}_{0.8} \mathrm{Ca}_{0.4+\times} \mathrm{Fe}_{2} \mathrm{O}_{5+\delta}(\mathrm{x}=0,0.25,0.4)$. S5

HAADF-STEM images and EELS mappings of a crystal of $\mathrm{GdBa}_{2} \mathrm{Ca}_{2} \mathrm{Fe}_{5} \mathrm{O}_{13}$ along the $[010]_{p}$ and $[-110]_{p}$ zone axis. S6

HAADF-STEM images and EELS mappings of a crystal of $\mathrm{Gd}_{2.2} \mathrm{Ba}_{3.2} \mathrm{Ca}_{2.6} \mathrm{Fe}_{8} \mathrm{O}_{21}$ along the $[010]_{p}$ and $[-110]_{p}$ zone axis.

TG analysis in air of $\mathrm{Gd}_{0.8-\mathrm{x}} \mathrm{Ba}_{0.8} \mathrm{Ca}_{0.4+x} \mathrm{Fe}_{2} \mathrm{O}_{5+\delta}(\mathrm{x}=0,0.25,0.4)$ in the temperature range between 100-900 ${ }^{\circ} \mathrm{C}$.

PXRD patterns of $\mathrm{Gd}_{0.8-\mathrm{x}} \mathrm{Ba}_{0.8} \mathrm{Ca}_{0.4+\mathrm{x}} \mathrm{Fe}_{2} \mathrm{O}_{5+\delta}(\mathrm{x}=0,0.25,0.4)$ and $\mathrm{GDC}$ mixtures.......S8

ASR values at different temperature of symmetrical cells GBCFO:CGO|CGO|GBCFO:CGO. S9 
Figure S1. PXRD patterns collected at room temperature of different oxides of the system $\mathrm{Gd}_{0.8-x} \mathrm{Ba}_{0.8} \mathrm{Ca}_{0.4+x} \mathrm{Fe}_{2} \mathrm{O}_{5+\delta}(\mathrm{x}=0,0.25,0.4)$. The reflections characteristic of the cubic perovskite structure are indicated with the corresponding Miller index and the superstructure reflections with an asterisk. Rietveld refinement results.
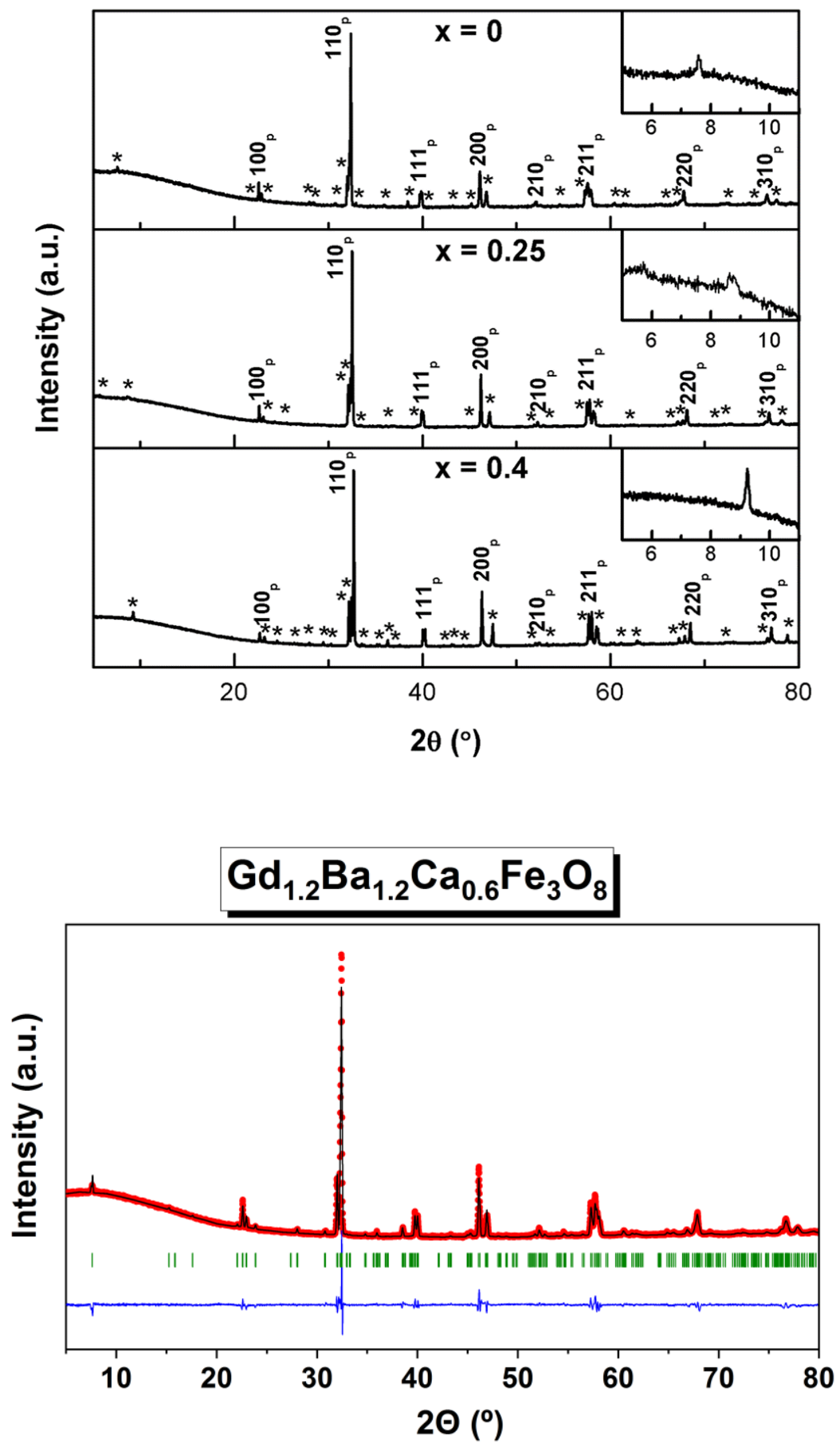

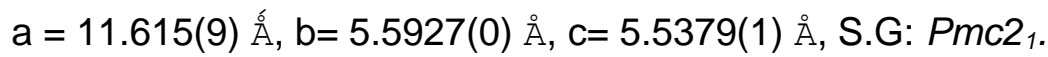

$R_{w p}=15.5 \%, R_{p}=19.6 \%, R_{\exp }=9.15 \%, X^{2}=6.69$. 


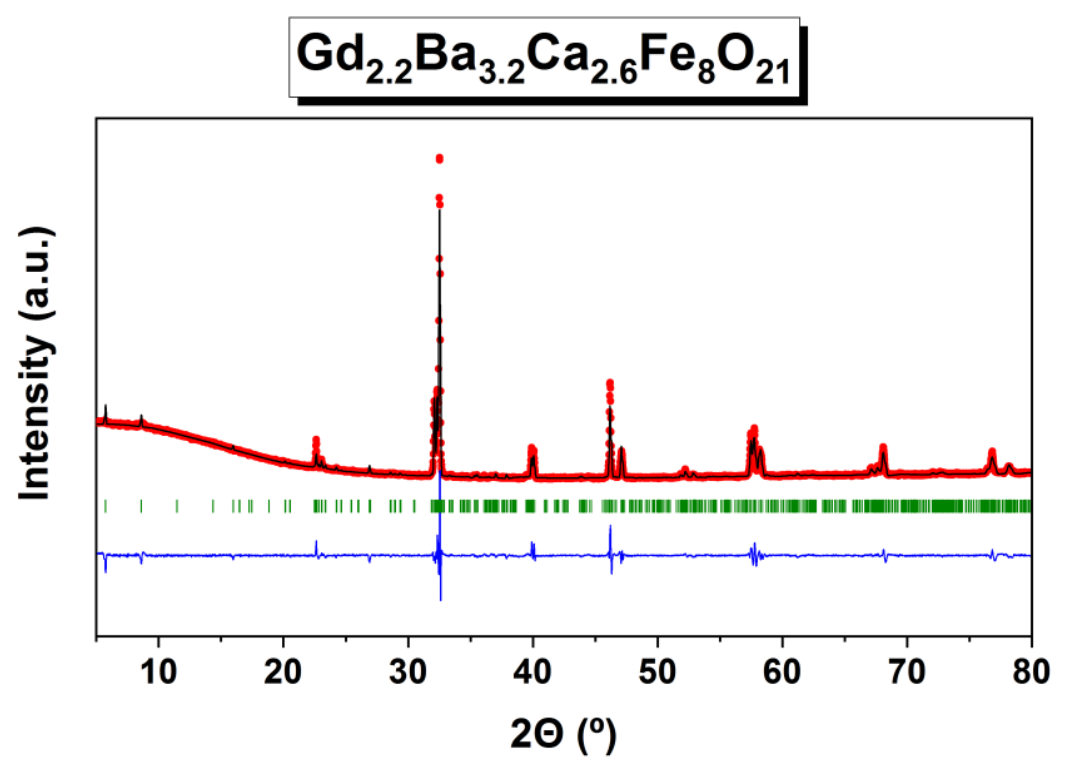

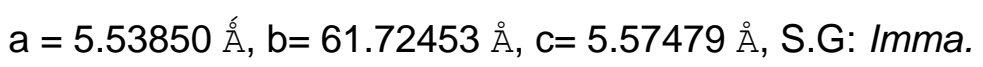

$$
R_{w p}=16.2 \%, R_{p}=20.6 \%, R_{\exp }=8.86 \%, X^{2}=10.1 \text {. }
$$

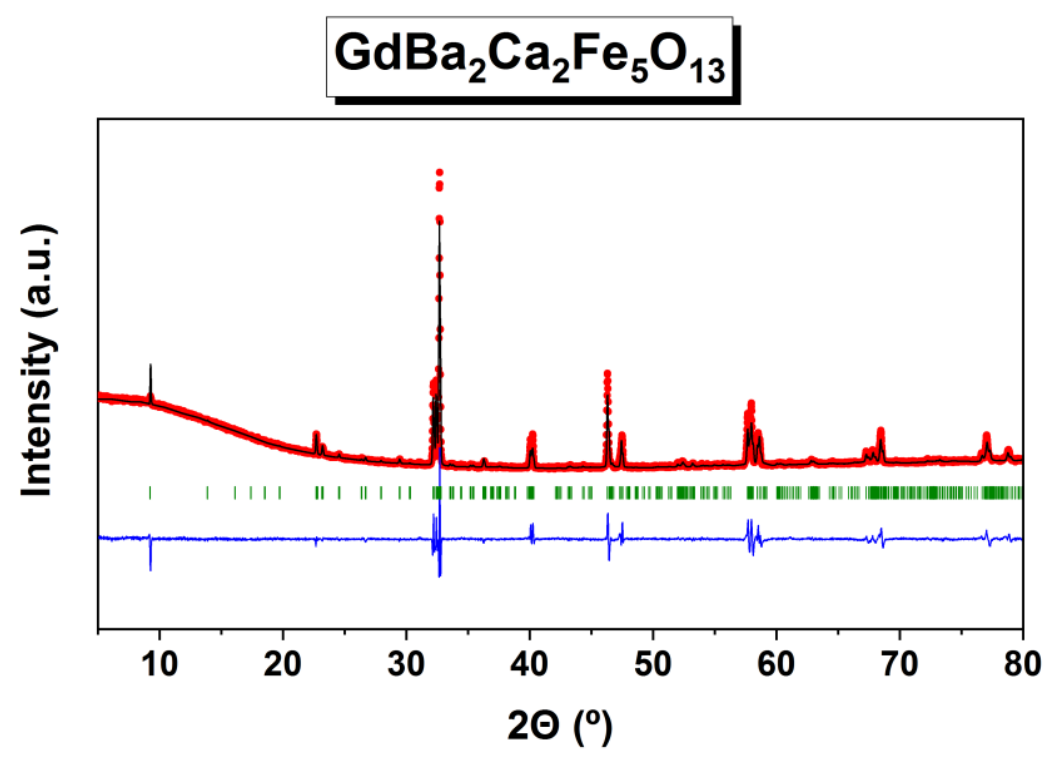

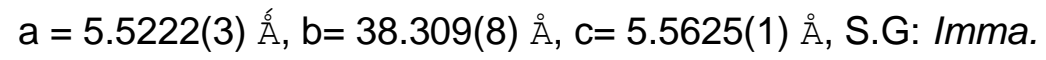

$$
R_{w p}=17.0 \%, R_{p}=21.4 \%, R_{\exp }=11.07 \%, X^{2}=10.8 .
$$


Figure S2. (a) $\mathrm{Fe}-\mathrm{L}_{2,3}$ ionization edge of $\mathrm{Gd}_{0.8-\mathrm{x}} \mathrm{Ba}_{0.8} \mathrm{Ca}_{0.4+x} \mathrm{Fe}_{2} \mathrm{O}_{5+\delta}(\mathrm{x}=0,0.25$ and 0.4 ). (b) Graphic representation of $\mathrm{L}_{3} / \mathrm{L}_{2}$ intensity ratio versus Fe oxidation state in standard Fe oxides and in the studied samples.
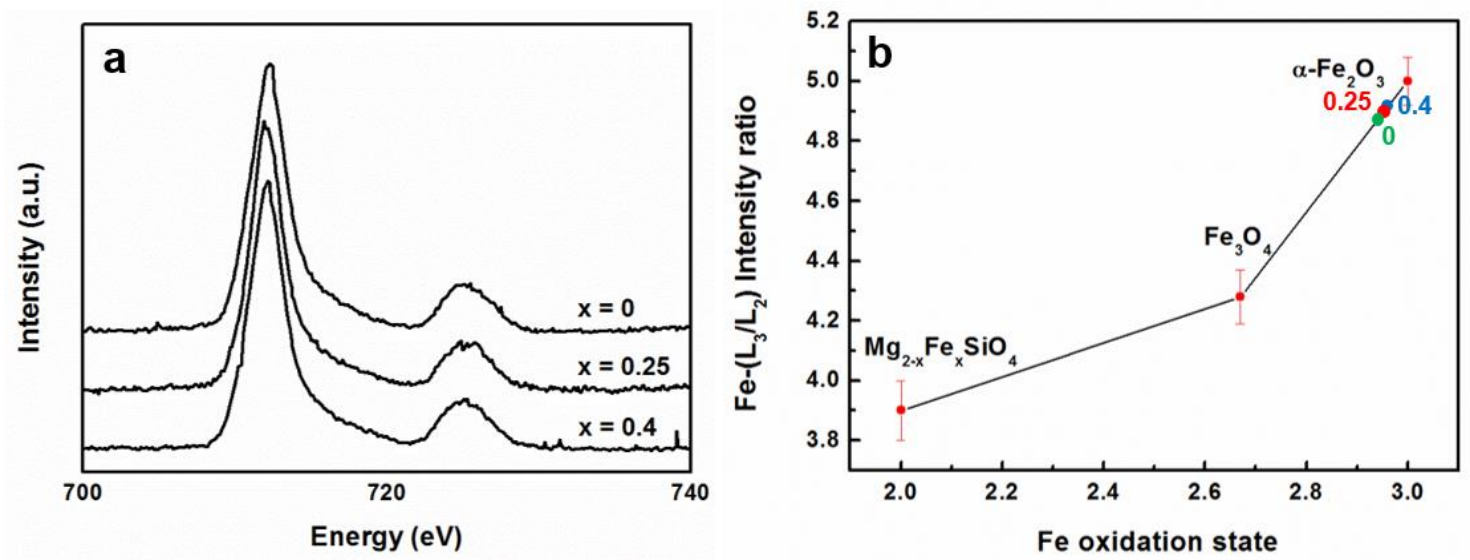
Figure S3. HAADF-STEM images along the $[010]_{p}(a, b)$ and the $[-110]_{p}(d)$ zone axes of a crystal of $\mathrm{GdBa}_{2} \mathrm{Ca}_{2} \mathrm{Fe}_{5} \mathrm{O}_{13}$. (c) EELS maps of the white marked area of the crystal indicated in (b).

Inset in (b) depicts the line-intensity profile along the green marked area showing five different layers. (e) and (f) show line-intensity profiles along the red and yellow marked areas in (d) (c) EELS maps of a crystal with [010] orientation. The maps have been taken in the white marked area in (b). These maps indicate that de Gd-layer between the two Ba-layers contains a slightly amount of $\mathrm{Ca}$ (blue boxes at (c)), which agreed with the intensity line profile result.

Like in $\mathrm{GdBa}_{2} \mathrm{Ca}_{2} \mathrm{Fe}_{5} \mathrm{O}_{13}$, in the $\mathrm{Gd}_{0.8} \mathrm{Ba}_{0.8} \mathrm{Ca}_{0.4} \mathrm{Co}_{0.6} \mathrm{Fe}_{1.4} \mathrm{O}_{5.41}$ oxide (rewritten according to the A-site ordering as $\mathrm{Gd}_{2} \mathrm{Ba}_{2} \mathrm{CaCo}_{1.5} \mathrm{Fe}_{3.5} \mathrm{O}_{13.52}$ ), the ordering of the $\mathrm{Gd}$, $\mathrm{Ba}$ and $\mathrm{Ca}$ along the c-axis also consists of five different layers (stacking sequence $\mathrm{Gd} / \mathrm{Ca}-\mathrm{Gd} / \mathrm{Ca}$ $\mathrm{Ba}-\mathrm{Gd}-\mathrm{Ba}-\mathrm{Gd} / \mathrm{Ca}$ ); however, in this oxide the $\mathrm{Gd}$-layer between the Ba-layers does not contain $\mathrm{Ca}$, but only $\mathrm{Gd}$ (19). This is due to the lower $\mathrm{Ca}$ content in the A-cation composition in $\mathrm{Gd}_{0.8} \mathrm{Ba}_{0.8} \mathrm{Ca}_{0.4} \mathrm{Co}_{0.6} \mathrm{Fe}_{1.4} \mathrm{O}_{5.41}$.
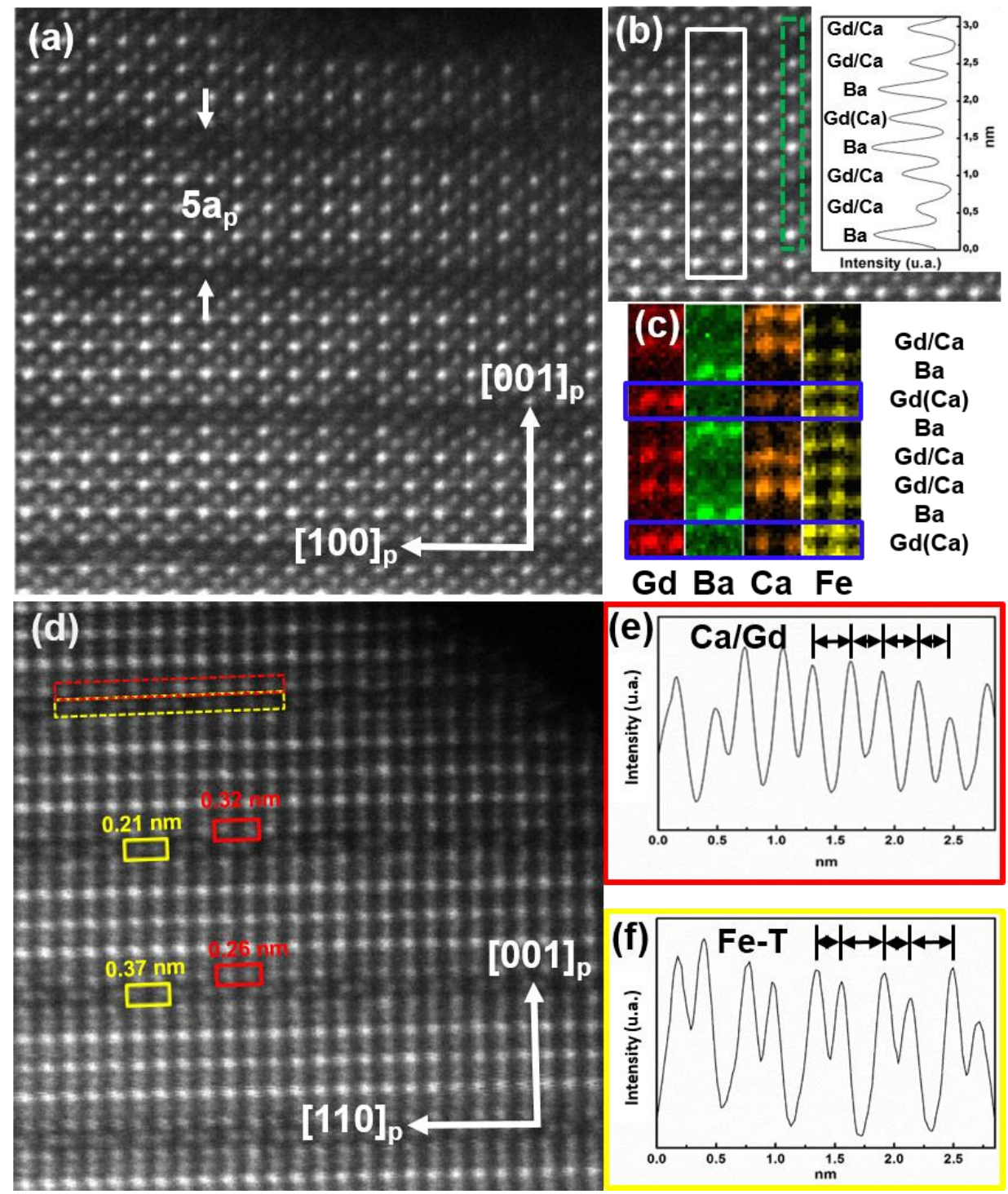
Figure S4. HAADF-STEM images along the $[010]_{\mathrm{p}}(\mathrm{a}, \mathrm{b})$ and the $[-110]_{\mathrm{p}}(\mathrm{d})$ zone axes of a crystal of $\mathrm{Gd}_{2.2} \mathrm{Ba}_{3.2} \mathrm{Ca}_{2.6} \mathrm{Fe}_{8} \mathrm{O}_{21}$. (c) EELS maps of the white marked area of the crystal indicated in (b). Line-intensity profile along the green marked area in (b) showing eight different layers. (e) and ( $f$ ) show line-intensity profiles along the red and yellow marked areas in (d). (c) EELS maps of a crystal with [010] p orientation. The maps have been taken in the white marked area in (b). These maps indicate that de Gd-layer between the two Ba-layers contains a slightly amount of $\mathrm{Ca}$ (blue box at (c)), which agreed with the intensity line profile result. The HAADF-STEM image of $\mathrm{Gd}_{2.2} \mathrm{Ba}_{3.2} \mathrm{Ca}_{2.6} \mathrm{Fe}_{8} \mathrm{O}_{21}$ along the $[-110]_{\mathrm{p}}$ zone axis $(\mathrm{d})$ reveals that, the shifting of the Featoms in tetrahedral-coordination along the $[110]_{p}$ direction giving two alternated distances $(0.38 \mathrm{~nm}$ and $0.24 \mathrm{~nm}$ ) induces that the $\mathrm{Gd} / \mathrm{Ca}$ atoms in the layers sandwiching these Fe-layers also suffer displacements along the [110] direction giving two alternated distances $(0.31 \mathrm{~nm}$ and $0.26 \mathrm{~nm}$ in this case). These two alternated distances of the columns of $\mathrm{Gd} / \mathrm{Ca}$ atoms run opposite each other along the c-axis in the consecutive $\mathrm{Gd} / \mathrm{Ca}$-layers, like in the Fe-layers, probably for relaxing electrostatic repulsions. The alternation of distances along [110 $]_{p}$ direction in both $\mathrm{Gd} / \mathrm{Ca}$-layers and Fe-layers is confirmed by the line intensity profiles run in the corresponding layers (e, f).
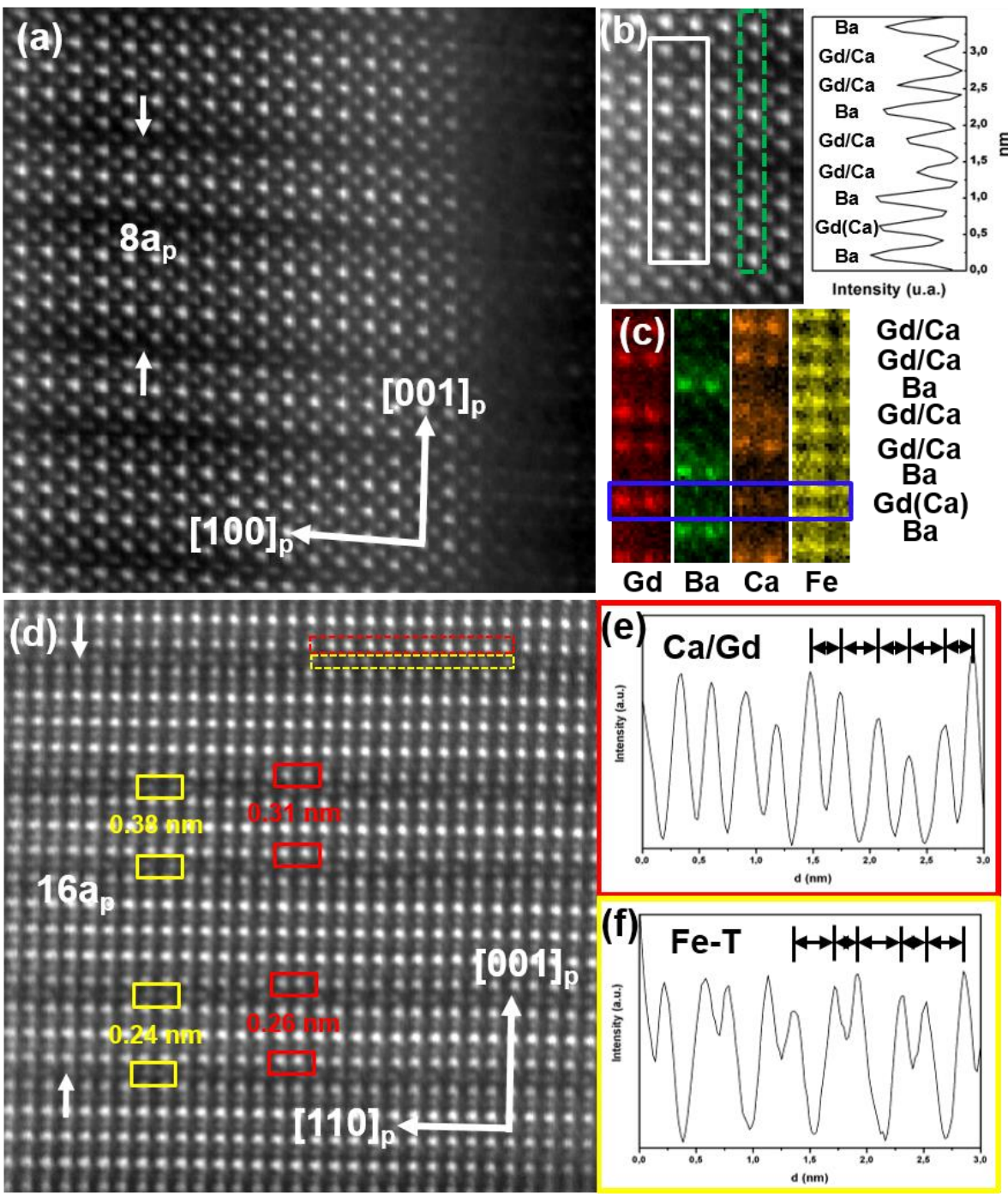
Figure S5. Thermogravimetric curves collected in ambient air of (a) $\mathrm{Gd}_{1.2} \mathrm{Ba}_{1.2} \mathrm{Ca}_{0.6} \mathrm{Fe}_{3} \mathrm{O}_{8}$, (b) $\mathrm{Gd}_{2.2} \mathrm{Ba}_{3.2} \mathrm{Ca}_{2.6} \mathrm{Fe}_{8} \mathrm{O}_{21}$ and (c) $\mathrm{Gd}_{1.0} \mathrm{Ba}_{2.0} \mathrm{Ca}_{2.0} \mathrm{Fe}_{5} \mathrm{O}_{13}$. Heating and cooling cycles are indicated by arrows. The small weight losing is related to adsorbed water or carbonates. The oxides do not suffer oxygen loss or gain when heating until $900^{\circ} \mathrm{C}$.
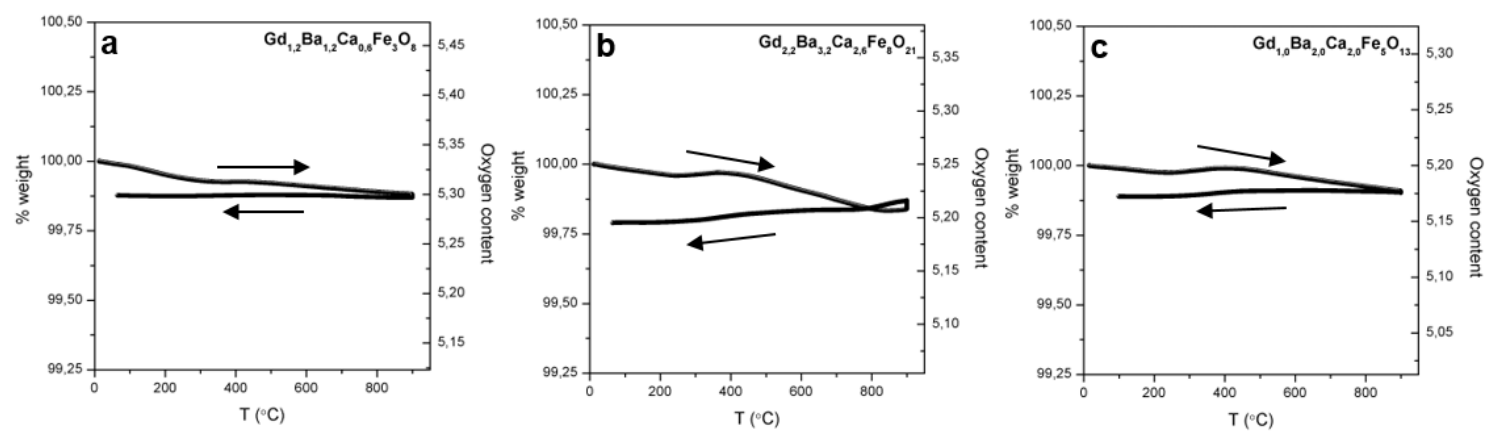

Figure S6. PXRD of mixtures of studied phases with GDC (50\% wt) after 5 days treatment at $1173 \mathrm{~K}$. GDC maximums are marked with green lines. No extra reflections resulting from reaction of the compounds are observed.

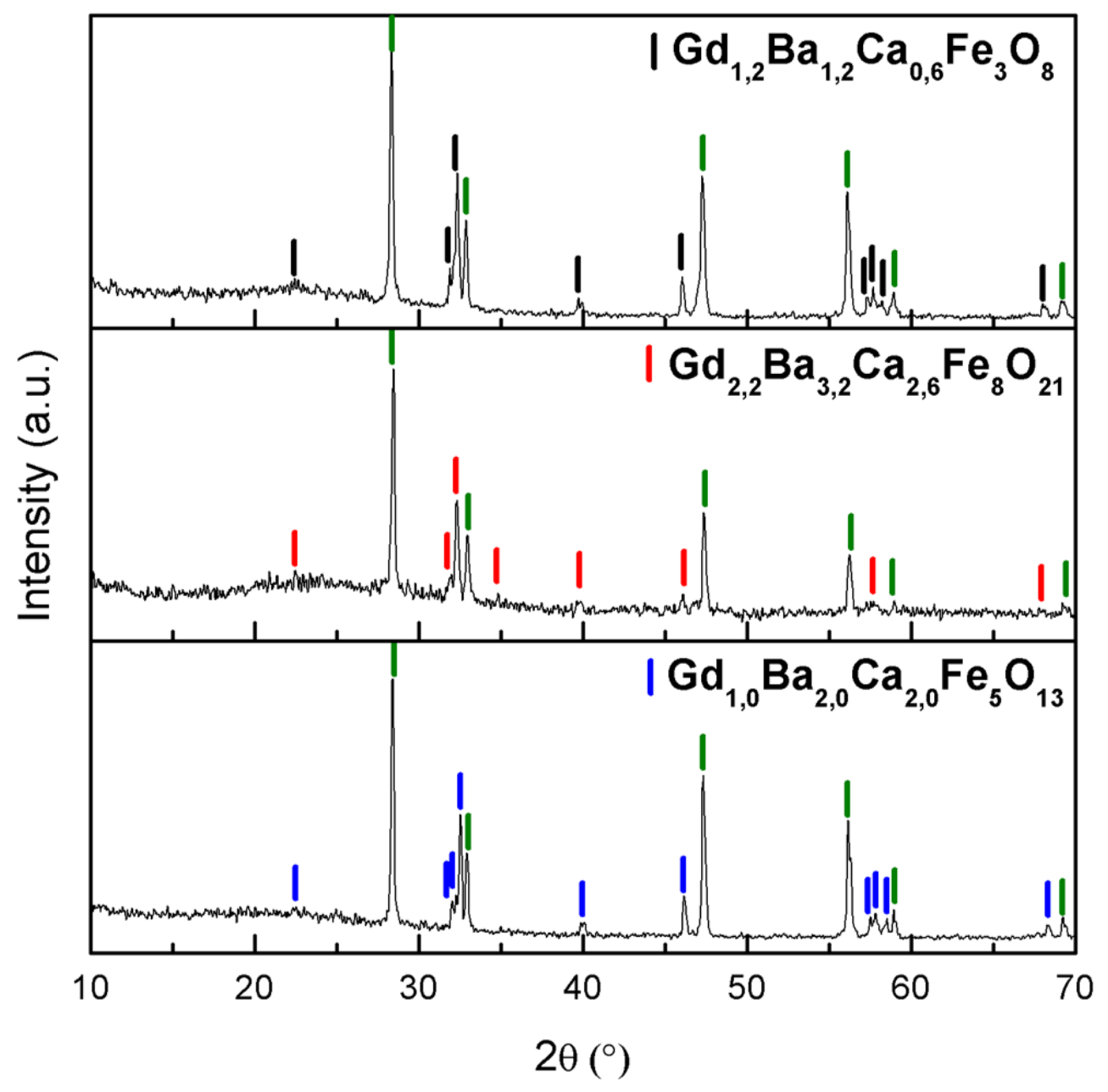


Table S1. ASR values at different temperature of symmetrical cells GBCFO:CGO|CGO|GBCFO:CGO.

\begin{tabular}{lccccc}
\hline \multirow{2}{*}{ Sample } & \multicolumn{5}{c}{$\mathrm{ASR}\left(\Omega \cdot \mathrm{cm}^{2}\right)$} \\
\cline { 2 - 6 } & $500^{\circ} \mathrm{C}$ & $550^{\circ} \mathrm{C}$ & $600^{\circ} \mathrm{C}$ & $650^{\circ} \mathrm{C}$ & $700^{\circ} \mathrm{C}$ \\
\hline $\mathrm{Gd}_{1.2} \mathrm{Ba}_{1.2} \mathrm{Ca}_{0.6} \mathrm{Fe}_{3} \mathrm{O}_{8}$ & 6.1 & 2.9 & 1.6 & 0.78 & 0.35 \\
$\mathrm{Gd}_{2.2} \mathrm{Ba}_{3.2} \mathrm{Ca}_{2.6} \mathrm{Fe}_{8} \mathrm{O}_{21}$ & 3.1 & 1.5 & 0.65 & 0.34 & 0.22 \\
$\mathrm{Gd}_{1.0} \mathrm{Ba}_{2.0} \mathrm{Ca}_{2.0} \mathrm{Fe}_{5} \mathrm{O}_{13}$ & 2.5 & 1.0 & 0.52 & 0.30 & 0.16 \\
\hline
\end{tabular}

